\title{
Surface Area, Volume, and Projected Area of Japanese-Shorthorn Cattle Measured by Stereo Photogrammetry Using Non-metric Cameras
}

\author{
Hideo Minagawa \\ ( $\left.\begin{array}{c}\text { School of Veterinary Medicine and Animal Sciences, } \\ \text { Kitasato University, Towada, Aomori, } 034 \text { Japan }\end{array}\right)$
}

\begin{abstract}
Three-dimensional measurement of five heads of Japanese-Shorthorn cattle was achieved using two non-metric cameras by stereo photogrammetry. The relationships between weight and surface area, volume, and projected area from side of the cattle were investigated. Surface area, volume, and projected area from side were exponentially related to weight. The exponential power was the greatest in volume. The ratio of surface area to projected area from side ranged from 3.1 at a weight of $600 \mathrm{~kg}$ to 2.9 at $750 \mathrm{~kg}$. This means that surface area can be obtained by tripling the projected area from side using a single photograph. The exponential power of volume with weight was closer to that of a basal energy metabolic power of 0.75 than that of surface area with weight. This implies that basal energy metabolism is not proportional to surface area but to volume. The close relationship between projected area from side and weight can be applied to estimate the weight of cattle by image analysis.
\end{abstract}

Key words: Japanese-shorthorn cattle, Projected area, Stereo photogrammetry, Surface area, Volume.

\section{Introduction}

Livestock and poultry have an irregular shape. To accurately measure the feature of an animal's shape is an essential part of understanding the interaction between the animal and its environment. Measurement of shape at various area of an animal is useful for estimating heat production or dissipation, understanding growth level, designing buildings and equipment, and breeding.

In the study of the shapes of animals, twodimensional surface area measurement has been done extensively to understand the relationship between surface area and rate of energy metabolism. The surface area of many animals has been determined by a roller integrator, a single photogrammetric, and other methods (Brody et al., 1928; Kleiber, 1961; Johnson and Ragsdale, 1961), and has been related to weight using an exponential formula. The one-dimensional size measurement of animals has been made with a ruler or a

Presented at the Annual General Meeting on August 8, 1990.

Accepted on April 15, 1994. pair of compasses to provide information for use in the designing buildings and equipment (ASAE, 1969; Wada and Notsuki, 1971). These studies, however, are not three-dimensional measurement of animals and their methods does not give information on the cross sectional shapes and volume of animals.

Three-dimensional measurement of a head of beef cattle with two similar non-metric cameras by stereo photogrammetry has been done and surface area and cross sectional shapes of head, body, and limbs have been reported by Minagawa (1988). The errors of the stereo pairs of photographs from the non-metric cameras was analyzed using a small pig model (Minagawa, 1994). The measurement of cattle surface area, however, may not be suitable for measuring many heads of cattle because the cameras were moved around the cattle, resulting in more time and less accuracy of stereo pairs of photographs. In this report, three-dimensional measurement of five heads of cattle was conducted by stereo photogrammetry with the improvement that the two non-metric cameras were fixed and the cattle was turned. The 
relationships between weight and surface area as well as between weight and volume and projected area from side were investigated.

\section{Materials and Methods}

\subsection{Experimental cattle and a stereo photograph- ing system}

At a farm of Kitasato University, a stage for stereo photographing a head of cattle was constructed with frame made from steel pipes $48 \mathrm{~mm}$ in diameter. The stage is shown in Fig. 1. Five heads of female beef cattle, Japanese-Shorthorn, ranging from a 4-year-old to a 13-year-old in age and ranging from $612 \mathrm{~kg}$ to $734 \mathrm{~kg}$ in weight, were used in the experiment. To take stereo pairs of photographs of the cattle in a short time, two cameras on a stereo bar were fixed at a site $4.0 \mathrm{~m}$ away from the cattle. Turning the cattle around the frame and putting it into the stage again in the opposite direction, stereo pairs of photographs were taken from the either sides of the cattle. A removable holding bar of the frame, with a cramp in front of the cattle, makes it easy to release from the stage and to close up the cattle again. The frame was made as small as possible to prevent the cattle from shading while taking the stereo pairs of photographs. To avert the limbs of the cattle from sinking into soil, a board of plywood $12 \mathrm{~mm}$ tick was placed on the floor of the stage.

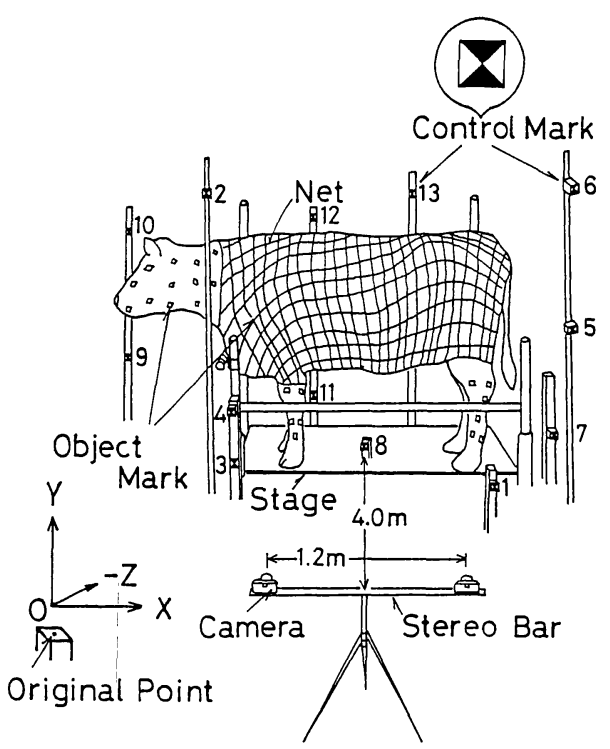

Fig. 1. Stage for taking stereo pairs of photographs of the cattle.
To calculate accuracy and three-dimensional coordinates of a point in a stereo pair of photographs, 13 control marks were placed on wooden stakes and steel poles around the cattle as shown in Fig. 1. The control marks were made of polyvinyl chloride hard film $0.2 \mathrm{~mm}$ thick, cut $40 \mathrm{~mm}$ square. Each control marks was split into four triangle parts painted black and white as shown in Fig. 1 , by the intersection of two diagonal lines to discriminate the cross point located at the center as the control point in a photograph. After an original point of the three-dimensional space coordinates was determined about $5 \mathrm{~m}$ away from the center of the stage floor, the principal directions of the $X, Y$, and $Z$ axes at the origin were defined with respect to the method of stereo photogrammetry (JSPRS, 1983, 1989). Threedimensional space coordinates of the control marks were measured with a transit, a level, and a tape measure to an accuracy of $1 \mathrm{~mm}$.

Cross points of a net, made of elastic string 7 $\mathrm{mm}$ wide, were used as the object marks to calculate three-dimensional coordinates of the cattle's surface. The size of a lattice of the net was about $100 \mathrm{~mm}$ square, and the net's cross points numbered about 600. The net was placed over the trunk of the cattle. On the fore and hind limbs and on the head of the cattle, approximately 50 object marks' that were of the same design as the control marks and were made of white tape $20 \mathrm{~mm}$ square' were attached. This was done because it was difficult to cover these areas with the net.

Two similar non-metric cameras (Nikon, F3) were used in the experiment. Both cameras had a $35 \mathrm{~mm}$ wide-angle lens with $28 \mathrm{~mm}$ focal distance and $2.8 \mathrm{f}$-stop. The cameras were mounted on the stereo bar made of L-type steel, separated $1.2 \mathrm{~m}$ from each other, making their optical axes parallel. Black-and-white panchromatic film (Fuji, Neopan SS of ASA/ISO 100), $36 \mathrm{mmby} 24 \mathrm{~mm}$ in size, was used in the cameras. When taking stereo pairs of photographs of the cattle, it was turned around in the stage and photographed in the opposite direction, resulting in approximately eight stereo pairs of photographs for the either sides of the cattle. The experiment was done in day light during June and September in 1989, when the summer hair would not affect their shapes. 


\subsection{Analysis of stereo pairs of photographs}

The films were developed and some films suitable for analysis were selected. They were printed and enlarged 7.0 times. Two stereo pairs of photographs for the left-hand and the right-hand sides of each head of cattle were analyzed. To get the errors of lens distortion and film flatness of the cameras, a method of single photogrammetric analysis reported by JSPRS $(1983,1989)$ was applied. The procedure was detailed in the former study (Minagawa, 1994). Two-dimensional photograph coordinates of the control marks in each stereo pair of photographs were measured with a digitizer (Mutho, DL3-22) connected to a personal computer (NEC, PC-9800).

To obtain the surface area of the cattle, cross sectional shapes of the cattle were drawn with an XY-plotter (Graphtec, WX-4636R) using the space coordinates of the object marks on the cattle. The pieces formed with neighboring cross sections of the cattle may look cylindrical or conical (Birkebak, 1966). The surface area and volume of the pieces were calculated with Eq. (1), assuming the shape of a truncated cone.

$$
\left.\begin{array}{l}
A=\pi l\left(r_{1}+r_{2}\right) \\
V=\pi h\left(r_{1}^{2}+r_{1} r_{2}+r_{2}^{2}\right) / 3
\end{array}\right\}
$$

where the terms $A$ and $V$ are the surface area and volume of a truncated cone, respectively, $\left(r_{1}, r_{2}\right)$ the equivalent radius of both cross sections of the cone, $l$ the slant length of the cone, $h$ the height of the cone. The circumference of the crosssections was measured with a planimeter (Ushikata, X-PLAN360). To obtain the projected area of the cattle, we used a right-hand side photograph of the stereo pair of photographs, tracing the circumference of the cattle with the planimeter and not taking into account the ears and tail because of their undesirable posture for analyzing.

\section{Results and Discussion}

3.1 Errors in the three-dimensional space coordinates of the control marks in the stereo pair of photographs

As an example of error estimation of a point in a stereo pair of photographs, three-dimensional space coordinates of the control marks were calculated and were compared with the measured coordinates. Fig. 2 shows a comparison of estimated space coordinates with actually measured space
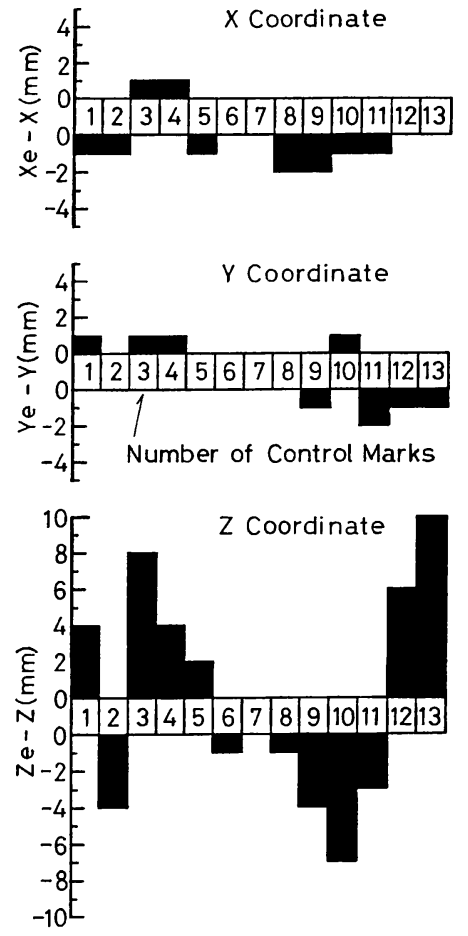

Fig. 2. Comparison of estimated space coordinates $\left(X_{\mathrm{e}}, \mathrm{Y}_{\mathrm{e}}, Z_{\mathrm{e}}\right)$ with measured space coordinaties $(X, Y, Z)$ of the control marks.

coordinates of the control marks on the right-hand side of the cattle. The errors of the $X$ and $Y$ coordinates of the control marks were within \pm 2 $\mathrm{mm}$, and the error of $Z$ coordinate within $\pm 10 \mathrm{~mm}$ or less. These errors were compared with the errors predicted with Eq. (2) (JSPRS, 1983). The Eq. (2) gives the estimated errors as $\sigma_{X}=\sigma_{Y}=$ $\pm 5 \mathrm{~mm}$ for the $X$ and $Y$ coordinates and $\sigma_{Z}=$ $\pm 18 \mathrm{~mm}$ for the $Z$ coordinate. This means. that the measurements were relatively accurate.

$$
\left.\begin{array}{l}
\sigma_{X}=\sigma_{Y}=(H / f / c) \sigma_{P} \\
\sigma_{Z}=(H / f / c)(H / L) \sigma_{P}
\end{array}\right\}
$$

where the terms $\sigma_{X}$ and $\sigma_{Y}$ are the errors for the $X$ and $Y$ coordinates orienting the object plane, $\sigma_{Z}$ the error for the $Z$ coordinate with respect to depth, $\sigma_{P}$ the error of the digitizer in measuring the two-dimensional photograph coordinates of a point, $L$ the base length between optical centers of cameras, $H$ the distance between camera's optical center and the object, $f$ the focal distance of the camera, and $c$ the enlargement power of the photograph from the film. Given quantities are $\sigma_{P}=$ $\pm 0.26 \mathrm{~mm}, L=1,200 \mathrm{~mm}, \quad H=4,000 \mathrm{~mm}, f=28$ 
$\mathrm{mm}$, and $c=7.0$.

\subsection{Surface area and volume of the cattle}

After calculating three-dimensional space coordinates of the object marks on each stereo pair of photographs, the sites of cross sections for the cattle were selected, spaced about $120 \mathrm{~cm}$ from the nose to the tail and the limbs of the cattle. A cross sectional shape can be obtained when the $X$ and $Y$ coordinates of the object marks on the circumference of a cross section are interpolated by a cubic curve using a spline function. Surface and volume of the cross section pieces formed with the neighboring cross section were calculated using Eq. (1). The surface area and volume at head, neck, chest and shoulder, abdomen and back, waist and hip, and fore and hind limbs of the cattle are shown in Table 1. The ear's surface areas were included in the head, and the tail's surface area in the waist and hip. The portions defined in Table 1 are shown in Fig. 3.

Although the surface area of each portion differed in each animals, the ratio of the surface area of abdomen and back to the whole surface remained constant approximately $40 \%$. In volume, the abdomen and back accounted for $40 \%$ to $60 \%$, a significant portion, but the fore and hind limbs accounted for only $3 \%$ to $4 \%$, while with respect to the surface area, $6 \%$ to $11 \%$. In head, the ratio of surface area to volume ranged between 2.0 to 2.7. The limbs and head may be different in skeletal structure from other portions. The density of the cattle, the weight divided by the total volume, is $0.972 \mathrm{~kg} \cdot \mathrm{m}^{-3}$ on average with a standard deviation of $0.0426 \mathrm{~kg} \cdot \mathrm{m}^{-3}$. The density of cattle is close to that of water.

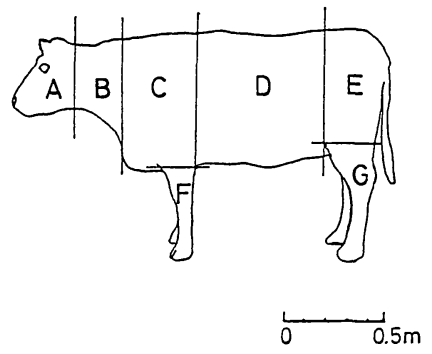

Fig. 3. Divided parts of the cattle referenced in Table 1. (The part A is head, B neck, $C$ chest and shoulder, $\mathrm{D}$ abdomen and back, $\mathrm{E}$ waist and hip, F fore limbs, and $\mathrm{G}$ hind limbs.)

Table 1 Surface area and volume at head, neck, chest and shoulder, abdomen and back, waist and hip, and fore and hind limbs of the cattle.

\begin{tabular}{|c|c|c|c|c|c|c|c|c|c|}
\hline \multicolumn{2}{|c|}{$\begin{array}{l}\text { Cattle No. } \\
\text { (Weight, Years) }\end{array}$} & $\begin{array}{l}\text { Head* } \\
A^{* * *}\end{array}$ & $\begin{array}{c}\text { Neck } \\
\text { B }\end{array}$ & $\begin{array}{c}\text { Chest \& } \\
\text { Shoulder } \\
\text { C }\end{array}$ & $\begin{array}{c}\text { Abdomen } \\
\text { \& Back } \\
\text { D }\end{array}$ & $\begin{array}{c}\text { Waist \& } \\
\text { Hip }^{* *} \\
\text { E }\end{array}$ & $\begin{array}{l}\text { Fore } \\
\text { Limbs } \\
\text { F }\end{array}$ & $\begin{array}{l}\text { Hind } \\
\text { Limbs } \\
\text { G }\end{array}$ & Total \\
\hline 1 & $\begin{array}{l}\text { Surface Area, } \mathrm{m}^{2} \\
\text { Fraction, } \%\end{array}$ & $\begin{array}{l}0.50(0.06) \\
9(1)\end{array}$ & $\begin{array}{l}0.26 \\
5\end{array}$ & $\begin{array}{l}0.66 \\
12\end{array}$ & $\begin{array}{l}2.36 \\
42\end{array}$ & $\begin{aligned} 0.97 & (0.09) \\
17(2) & \end{aligned}$ & $\begin{array}{l}0.34 \\
6\end{array}$ & $\begin{array}{l}0.49 \\
9\end{array}$ & $\begin{array}{l}5.58 \\
100^{5}\end{array}$ \\
\hline$(734 \mathrm{~kg}, 4)$ & $\begin{array}{l}\text { Volume, } \mathrm{m}^{3} \\
\text { Fraction, } \%\end{array}$ & $\begin{array}{l}0.031(0) \\
4(0)\end{array}$ & $\begin{array}{l}0.023 \\
3\end{array}$ & $\begin{array}{l}0.088 \\
12 \\
\end{array}$ & $\begin{array}{l}0.427 \\
59 \\
\end{array}$ & $\begin{array}{l}0.139(0.001) \\
19(0)\end{array}$ & $\begin{array}{l}0.009 \\
1 \\
\end{array}$ & $\begin{array}{l}0.015 \\
2 \\
\end{array}$ & $\begin{array}{l}0.732 \\
100\end{array}$ \\
\hline 2 & $\begin{array}{l}\text { Surface Area, } \mathrm{m}^{2} \\
\text { Fraction, } \%\end{array}$ & $\begin{array}{l}0.43(0.06) \\
9(1)\end{array}$ & $\begin{array}{l}0.28 \\
6\end{array}$ & $\begin{array}{l}0.85 \\
17\end{array}$ & $\begin{array}{l}1.82 \\
37\end{array}$ & $\begin{array}{r}0.75(0.08) \\
15(2)\end{array}$ & $\begin{array}{l}0.32 \\
6\end{array}$ & $\begin{array}{l}0.51 \\
10\end{array}$ & $\begin{array}{l}4.96 \\
100\end{array}$ \\
\hline$(612 \mathrm{~kg}, 4)$ & $\begin{array}{l}\text { Volume, } \mathrm{m}^{3} \\
\text { Fraction, } \%\end{array}$ & $\begin{array}{l}0.025(0) \\
4(0)\end{array}$ & $\begin{array}{l}0.025 \\
4\end{array}$ & $\begin{array}{l}0.123 \\
20\end{array}$ & $\begin{array}{l}0.312 \\
51\end{array}$ & $\begin{array}{l}0.106(0.001) \\
17(0)\end{array}$ & $\begin{array}{l}0.008 \\
1 \\
\end{array}$ & $\begin{array}{l}0.016 \\
3 \\
\end{array}$ & $\begin{array}{l}0.615 \\
100 \\
\end{array}$ \\
\hline 3 & $\begin{array}{l}\text { Surface Area, } \mathrm{m}^{2} \\
\text { Fraction, } \%\end{array}$ & $\begin{array}{l}0.43(0.07) \\
8(1)\end{array}$ & $\begin{array}{l}0.34 \\
6\end{array}$ & $\begin{array}{l}0.97 \\
17\end{array}$ & $\begin{array}{l}2.14 \\
38\end{array}$ & $\begin{array}{r}0.78(0.08) \\
14(1)\end{array}$ & $\begin{array}{l}0.36 \\
7\end{array}$ & $\begin{array}{l}0.57 \\
10\end{array}$ & $\begin{array}{l}5.59 \\
100^{2}\end{array}$ \\
\hline$(746 \mathrm{~kg}, 6)$ & $\begin{array}{l}\text { Volume, } \mathrm{m}^{3} \\
\text { Fraction, } \%\end{array}$ & $\begin{array}{l}0.024(0) \\
3(0)\end{array}$ & $\begin{array}{l}0.033 \\
4\end{array}$ & $\begin{array}{l}0.152 \\
19 \\
\end{array}$ & $\begin{array}{l}0.427 \\
55 \\
\end{array}$ & $\begin{array}{l}0.120(0.001) \\
15(0)\end{array}$ & $\begin{array}{l}0.011 \\
1 \\
\end{array}$ & $\begin{array}{l}0.018 \\
3 \\
\end{array}$ & $\begin{array}{l}0.785 \\
100\end{array}$ \\
\hline 4 & $\begin{array}{l}\text { Surface Area, } \mathrm{m}^{2} \\
\text { Fraction, } \%\end{array}$ & $\begin{array}{ll}0.35 & (0.07) \\
6(1) & \end{array}$ & $\begin{array}{l}0.26 \\
5\end{array}$ & $\begin{array}{l}0.96 \\
18\end{array}$ & $\begin{array}{l}2.20 \\
41\end{array}$ & $\begin{array}{r}0.73(0.06) \\
13(1)\end{array}$ & $\begin{array}{l}0.33 \\
6\end{array}$ & $\begin{array}{l}0.59 \\
11\end{array}$ & $\begin{array}{l}5.42 \\
100\end{array}$ \\
\hline$(655 \mathrm{~kg}, 13)$ & $\begin{array}{l}\text { Volume, } \mathrm{m}^{3} \\
\text { Fraction, } \%\end{array}$ & $\begin{array}{l}0.017(0) \\
3(0)\end{array}$ & $\begin{array}{l}0.021 \\
3 \\
\end{array}$ & $\begin{array}{l}0.142 \\
19 \\
\end{array}$ & $\begin{array}{l}0.418 \\
57 \\
\end{array}$ & $\begin{array}{l}0.103(0.001) \\
14(0)\end{array}$ & $\begin{array}{l}0.009 \\
1 \\
\end{array}$ & $\begin{array}{l}0.020 \\
3 \\
\end{array}$ & $\begin{array}{l}0.730 \\
100 \\
\end{array}$ \\
\hline 5 & $\begin{array}{l}\text { Surface Area, } \mathrm{m}^{2} \\
\text { Fraction, } \%\end{array}$ & $\begin{array}{r}0.56(0.07) \\
10(1)\end{array}$ & $\begin{array}{l}0.36 \\
7\end{array}$ & $\begin{array}{l}0.76 \\
14\end{array}$ & $\begin{array}{l}2.13 \\
40\end{array}$ & $\begin{array}{r}0.72(0.08) \\
14(2)\end{array}$ & $\begin{array}{l}0.36 \\
7\end{array}$ & $\begin{array}{l}0.42 \\
8\end{array}$ & $\begin{array}{l}5.31 \\
100^{5}\end{array}$ \\
\hline$(630 \mathrm{~kg}, 13)$ & $\begin{array}{l}\text { Volume, } \mathrm{m}^{3} \\
\text { Fraction, } \%\end{array}$ & $\begin{array}{l}0.036(0) \\
5(0)\end{array}$ & $\begin{array}{l}0.038 \\
5\end{array}$ & $\begin{array}{l}0.115 \\
16\end{array}$ & $\begin{array}{l}0.400 \\
57\end{array}$ & $\begin{array}{l}0.099(0.001) \\
14(0)\end{array}$ & $\begin{array}{l}0.008 \\
1\end{array}$ & $\begin{array}{l}0.013 \\
2\end{array}$ & $\begin{array}{l}0.709 \\
100\end{array}$ \\
\hline
\end{tabular}

Note: *Head includes ears, and **Waist \& Hip a tail. The parts ***A to $\mathrm{G}$ are shown in Fig. 3 . The figures in the parentheses of Head and Waist \& Hip mean the portions for the ears and the tail, respectively. 
Surface area of an animal is more meaningful when the appendages such as limbs, tail, and ears are considered in relation to the total surface area. Johnson and Ragsdale (1961) reported that percentages of the surface area in limbs and tail, and ears were $24 \%$ and $2 \%$, respectively, on average for three kinds of dairy calves, Holstein, Brown Swiss, and Jersey. These proportions are greater than that of this experiment because of the difference in age and breed.

3.3 Relationships between weight and surface area as well as between weight and volume and projected area from side of the cattle

Fig. 4 depicts the relationships between weight and total surface area and total volume as well as between weight and projected area from the righthand side of the cattle. The projected area from side does not include the ears and tail. The total surface area, total volume, and projected area from side were exponentially related to the live weight. The exponential power of weight was greatest in the volume. The ratio of total surface area to projected area from side was calculated using the regression equations of total surface area, $S_{\mathrm{a}}$, and projected area, $P_{\mathrm{a}}$, with weight, $W$, as shown in Fig. 4. The ratio ranged from 3.1 at a weight of $650 \mathrm{~kg}$ to 2.9 at $750 \mathrm{~kg}$. This means that total surface area can be obtained by tripling the projected area from side using a single photograph. Total surface area and total volume are important factors for basal energy metabolic rate in animals.

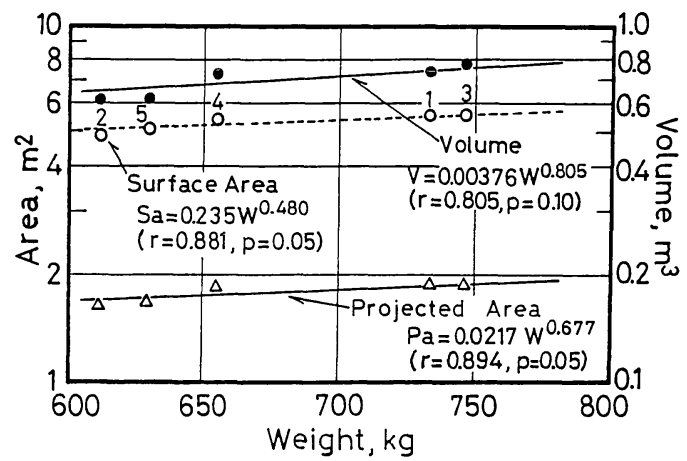

Fig. 4. The relationships between weight and total surface area and total volume as well as between weight and projected area from the right-hand side of the cattle. (The term $r$ is the correlation coefficient and $p$ the significance level, and the numbers below the black circles mean the experimented cattle as shown in Table 1.)
The exponential power of the total volume with weight was closer to that of the basal energy metabolic rate with weight, a power of 0.75 for many kinds of animals (Kleiber, 1961), than that of the total surface area with weight. This implies that basal energy metabolism is not proportional to surface area but to volume.

Brody et al:(1928) reported that the relationship of total surface area and weight for about two hundred heads of dairy and beef cattle is $S_{\mathrm{a}}=$ $0.13 W^{0.56}$. Johnson and Ragsdale (1961) showed the relationship of $S_{\mathrm{a}}=0.14 W^{0.56}$ for Shorthorn calves. The exponential power achieved in this experiment is $14 \%$ lower than that of the Brody's and Johnson and Regsdale's equations. More database is needed to confirm the discrepancy. The close relationship between projected area from side and weight can be applied to estimate the weight of cattle by image analysis.

\section{Conclusions}

Three-dimensional measurement of five heads of cattle was conducted by stereo photogrammetry with the improvement that the two non-metric cameras were fixed and the cattle was turned. The relationships between weight and surface area as well as between weight and volume and projected area from side were investigated. The results are as follows:

1) Surface area, volume, and projected area from side of the cattle were exponentially related to their live weight. The exponential power of weight was greatest in the volume.

2) The ratio of surface area to projected area from side ranged from 3.1 at a weight of $600 \mathrm{~kg}$ to 2.9 at $750 \mathrm{~kg}$. Surface area can be obtained by tripling the projected area from side by a single photograph.

3) The exponential power of volume with weight was closer to that of a basal energy metabolic power of 0.75 than that of surface area with weight. This implies that basal energy metabolism is not proportional to surface area but to volume.

4) Close relationship between projected area from side and weight can be applied to estimate the weight of a cattle by image analysis.

\section{Acknowledgments}

Thanks are due to Y. Abo, T. Saito, H. Tadano, 
and M. Takahashi, students at Kitasato University. for their help with the experiments.

\section{References}

ASAE, 1969: Dimensions of livestock and poultry (ASAE data D321). In Agricultural engineering yearbook. Amer. Soc. Agr. Engineers, St. Joseph, Michigan, 381-387.

Birkebak, R. C., 1966: Heat transfer in biological systems. Inter. Rev. Gen. Exptl. Zool., 2, 269344.

Brody, S., Comfort, J. E. and Matthews, J. S., 1928: Growth and development XI. Further investigations on surface area with special reference to its significance in energy metabolism. Mo. Agr. Exp. Sta. Res. Bul., 115, 60p.

Johnson, H. D. and Ragsdale, A. C., 1961: Environmental physiology and shelter engineering LVII. Surface area determinations of beef and dairy calves during growth at $50^{\circ} \mathrm{F}$ and $80^{\circ} \mathrm{F}$ environmental temperatures. Mo. Agr. Exp. Sta. Res. Bul., 770, 27p.
JSPRS, 1983: Three-dimenșional measurement b.y photogrammetry (in Japanese). Japan Soc. Photogrammetry and Remote Sensing, Kyouritsu Pub., Tokyo, 182p.

JSPRS, 1989: Analytical photogrammetry (rev. edit. in Japanese). Japan Soc. Photogrammetry and Remote Sensing, Tokyo, 163p.

Kleiber, M., 1961: The fire of life. Wiley, New York, 454p.

Minagawa, H., 1988: Measurement of cattle body surface area by stereo photogrammetry. In Proc. of the third intern. livestock environment symp. Amer. Soc. Agr. Engineers Pub. 1-88, 179-185.

Minagawa, H., 1994: Errors in determining the surface area of a small pig model by stereo photogrammetry using non-metric cameras (in progress). J. Agr. Met., Tokyo.

Wada, T. and Notsuki, I., 1971: Body dimensions of livestock for barn design (in Japanese). $J$. Soc. Agr. Struc. Japan, 2 (1), 45-61.

\title{
沉用カメラを用いた立体写真測量法による日本短角種 成牛の体表面積，体積，および投影面積の測定
}

\author{
皆川秀夫
}

（北里大学獣医畜産学部）

\begin{abstract}
要
約

沉用カメラ 2 台を用い，立体写真測量法により，日本 短角種成牛 5 頭の 3 次元形状を測定し, 体重と体表面積, 体積，および側方投影面積との関係を検討した。供試牛 の体表面積, 体積, および側方投影面積と体重とは指数 関係を示し, 高い相関があることがわかった。体積が最 あ大きな指数を示した。体表面積と側方投影面積との比 は体重が $600 \mathrm{~kg}$ のとき 3.1 から, $750 \mathrm{~kg}$ のとき 2.9 まで の範囲にあった。乙れは単写真の側方投影面積を 3 倍す

ることにより体表面積が得られることを意味する。体積 に㧍ける体重の指数は, 体表面積のそれに比し, 基礎代 謝における体重の指数 0.75 亿近い值となった。乙れは基 礎代謝が体表面積よりも体積に比例することを示唆して いる。側方投影面積と体重との高い相関を利用して画像 解析により牛の体重を推定できる可能性がある。 キーワード：体積, 体表面積, 投影面積, 日本短角種成 牛, 立体写真測量法
\end{abstract}

